\title{
THE RELATIONSHIP BETWEEN ADOLESCENTS' PHYSICAL INACTIVITY AND HEALTH
}

\author{
Neringa Strazdienè \\ Klaipèda University, Lithuania \\ Eugenija Adaškevičienè \\ Klaipèda University, Lithuania
}

\begin{abstract}
The research aim is to reveal the interrelationship between adolescents' sedentary lifestyle, physical inactivity, and health. The research methods include analysis of scientific literature, questionnaire survey, and mathematical statistical analysis of quantitative data. 528 schoolchildren (aged 13 to 14 years) and 520 parents participated in our survey. Most of the adolescents indicated being healthy or completely healthy, however, about half of the children had some health complaints over the last six months: headache, nervous tension, insomnia, dizziness, or weakness. The adolescents' indispositions could be related to the learning load and long periods of sitting, and especially insufficient physical activity in the fresh air. Nearly half of the parent respondents believed their children did not have enough time due to heavy learning loads at school and at home. The majority of the parents indicated that their children spent a lot of time at the computer. The schoolchildren respondents who attended additional private lessons and non-formal education activities were characterised by a higher level of inactivity. Adolescents' physical inactivity is related to the time spent on ICT (computers, TV), the frequency of their choice, and the duration of doing their homework.
\end{abstract}

Keywords: adolescents, health, physical inactivity.

\section{Introduction}

Scientific and technological achievements improve the quality of human life, reduce the need for manual labour, and predetermine high quality standards for intellectual education. The educational technologies that have existed in schools for centuries are complemented by new information and communication technologies. Currently, schools are rapidly installing educational software programmes, electronic textbooks, and the Internet, allowing access to open learning environments, hypertexts, and microworlds. Changes in the learning environment, new educational technologies in the (self-) education reality, and virtual communication offer new opportunities for effective learning, for the acquisition of new knowledge, and for being in the centre of the current events. The experience is important for the personality maturity. As emphasised by scientists, the media (computer, TV, etc.) have turned into a transforming social 
power which preconditions young people's lifestyles. Schoolchildren in particular spend a lot of time sitting in front of the computer and TV screens, writing text messages, and talking on mobile phones (Biddle et al., 2004; Hastings et al., 2009; Patel at al., 2010; Uznienè, 2010; Andrijauskas \& Batutis, 2013; Nedovic \& Morrissey, 2013).

In various research studies and recommendations, physical inactivity is frequently defined as a health risk factor. As revealed by recent studies, physical inactivity is considered to be one of the major chronic non-communicable diseases risk factors (WHO, 2002, 2004, 2010; Bouchard at al., 2007; Skurvydas, 2008; Horton, 2009; Dugdill at al., 2009). Long-term sitting activities are related to the imbalance between energy intake and energy expenditure and often become a cause of numerous diseases: cardiovascular (Boreham \& Riddoch, 2001; Andriuškienè at al., 2007; Sarradel et al., 2011; Glazer et al., 2013), metabolic syndrome (Healy et al., 2008; Baceviciene at al., 2012), overweight and obesity (Dencker et al., 2006; Stokkenes \& Fougner, 2011), or mental health (Bertheussen et al., 2011; Helgadóttir at al., 2015; Brunes at al., 2013). In accordance with research data, the children who spend hours in front of computer and TV screens experience more psychological problems. Compared to their peers, they find it more difficult to communicate and cooperate, they tend to be hyperactive and face psychological problems. As emphasised by D. G. Mayers (2008), the children who spend much time in front of the screens feel anxiety and fear of violence manifestations in the surrounding world. A. Zaborskis, A. Raskilas (2011) argue that the children and adolescents who do not move enough are put at risk of obesity and cardiovascular diseases or can demonstrate symptoms of depression. J. Doveikiene (2011) notes that adolescents are already affected by senile diseases. 12 to 14-year olds are diagnosed with spinal osteochondrosis and disk herniation. Incorrect prolonged sitting without moving, tense eye muscles, and too small disctance from the screen cause the computer vision syndrome which manifests itself through symptoms including eye dryness, itching, irritation, and redness, and also disrupts the functions of bones, muscles, and the circulatory system. Immobility has a negative impact on the psyche of such children, their cognitive function becomes worse, and they find it difficult to concentrate during lessons. Because of immobility, their irritability increases and the sleep is disturbed.

Thus, physical inactivity and the lack of exercise in adolescence is harmul to one's health and forms an inactive lifestyle stereotype. The sedentary lifestylecaused harm is difficult to compensate for even by physical loads, especially if adolescents take part in sporting activities irregularly. All that motivates the search for promising insights related not merely to the correction and management of the media impact, but also to the optimisation of the health-conducive physical 
activity, especially during leisure time, and to its integration into the teaching/learning at school and after school.

The object of research is adolescents' sedentary lifestyle, physical inactivity, and health.

The aim of the research is to reveal the interrelationship between adolescents' sedentary lifestyle, physical inactivity, and health.

Research methods: analysis of scientific literature, questionnaire survey, mathematical statistical analysis of quantitative data.

In 2012, opinion surveys of the schoolchildren of Lithuanian comprehensive schools and of their parents were carried out. Two questionnaires were developed: one for schoolchildren who attended lessons of physical education, however, took no part in the process of non-formal physical education, and the other for parents raising 13 to 14 -year-old children. The respondents of the survey were 528 schoolchildren (13 to 14-year olds) from 14 comprehensive schools in four Counties of the Republic of Lithuania (those of Klaipeda, Kaunas, Šiauliai, and Tauragè), selected for the survey by means of convenience sampling in different type schools. 520 parents took part in the survey. About half $(53,7 \%)$ of the parent respondents had higher university education, 17,3\% were college graduates, 16 $\%$ had special secondary education, $9,3 \%$, secondary education, and 3,7 \%, basic education.

The data of the survey were processed by the SPSS software programme (version 22.0), and MS Excel calculator 2007. To determine correlation, Spearman's correlation coefficient $(r)$ was used, whose values ranged from 0 to \pm 1 . The evaluations of the empirical $r$ values were: from 0 to $+0,3$, a weak direct link; from $+0,3$ to $+0,7$, a average direct link; from $+0,7$ to +1 , a strong direct link; from 0 to $-0,3$, a weak inverse link; from $-0,3$ to $-0,7$, an average inverse link; and from $-0,7$ to -1 , a strong inverse link.

\section{Adolescents' evaluation of their own health and indispositions felt}

The majority of adolescents felt quite positive about their health. Through the analysis of 13 and 14-year-old respondents separately, it was established that most $(78,3 \%)$ of the 13-year-old adolescents (boys and girls) indicated they were "healthy" or "completely healthy", and among 14-year-old adolescents, the "healthy" ones accounted for $77,4 \%$, i.e. by $0,9 \%$ less (Fig. 1 ). When comparing the answers with respect to the gender, it was obvious that more boys than girls both in the group of 13-year-olds $\left(\chi^{2}=6,07, \mathrm{df}=4, \mathrm{p}<0,193\right)$ and of 14 -year-olds felt being "healthy" or "completely healthy". 


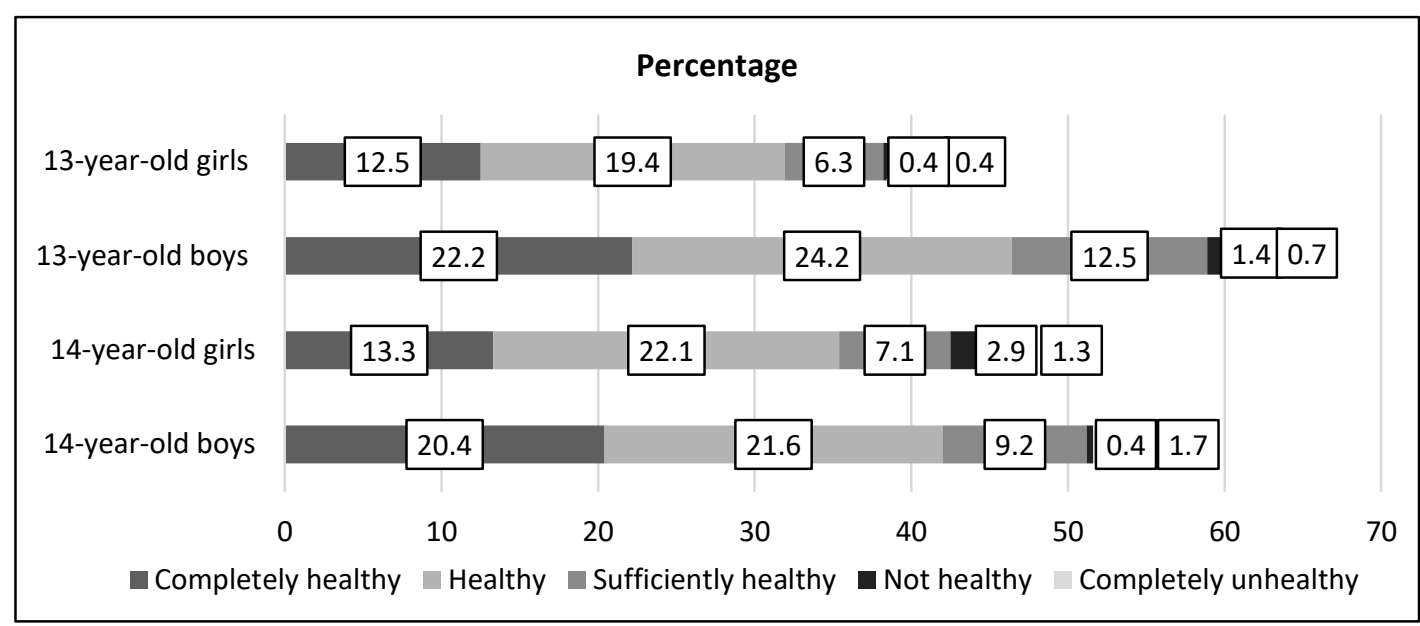

Fig.1 Percentage distribution of schoolchildrens' views of their own health by age and gender

It was noted that the adolescents evaluated their own health more positively than their parents. We sought to find out what indispositions were experienced by adolescents. 52,9\% of 13-year-old and 50,1\% of the 14-year-old adolescents said they were not feeling well. The rest stated that over the past six months they did not have any indispositions. A detailed analysis of the data proved that the majority of the respondents complained of headaches: 6,3\% of the 13-year-old girls and $8,7 \%$ of the boys, and respectively $1,3 \%$ of the 14 -year-old girls and $7,9 \%$ of the boys (Fig. 2).

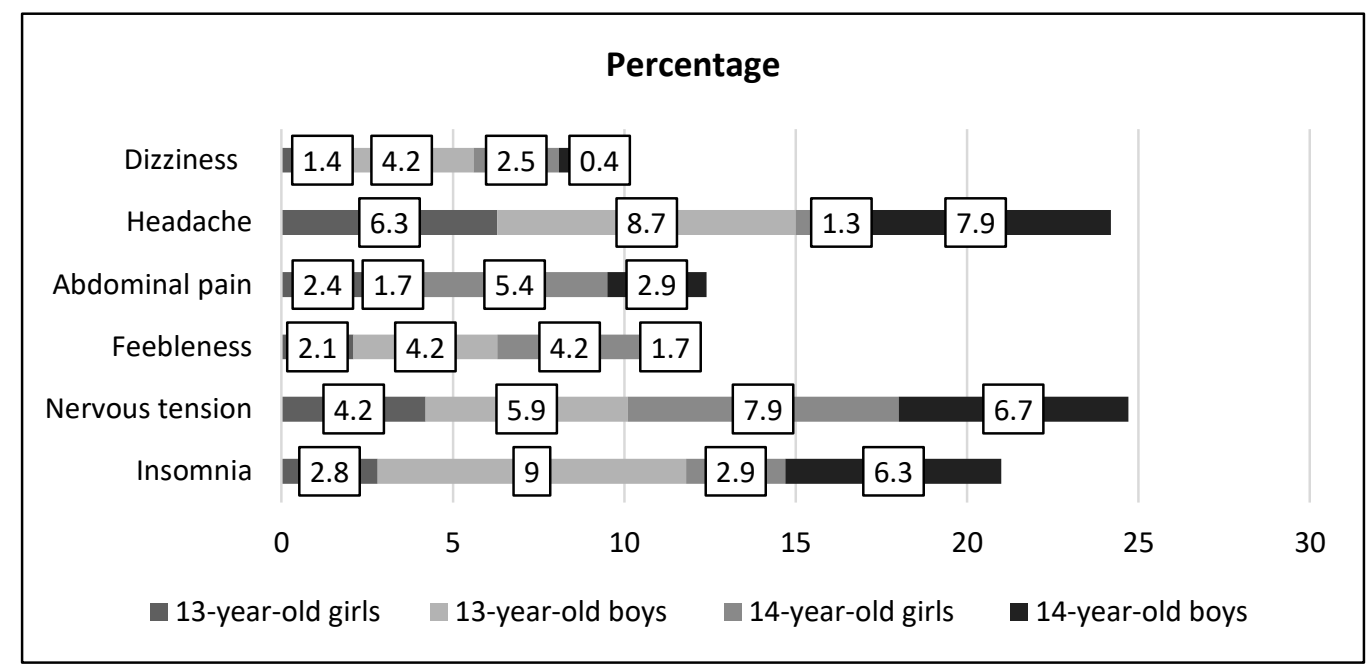

Fig.2 Percentage distribution of the adolescents' views of their indispositions

A slightly larger percentage of the 14-year-old girls $(7,9 \%)$ than of the 13 year-old girls $(4,2 \%)$ and a slightly larger percentage of the 14-year-old boys $(6,7 \%)$ than of the 13 -year-old boys $(5,9 \%)$ felt nervous tension. Some 
adolescents complained of addominal pains, insomnia, dizziness, and feebleness. No statistically significant differences between the boys and the girls were established.

\section{Parents' views on their children's sedentary lifestyle with respect to health}

As proved by the research carried out by M. Barkauskaite et al. (2004), $47 \%$ of the surveyed schoolchildren failed to do all the home assignments, as there were too many, 39,3\% felt tired and did not have the strength to do homework, and about $20 \%$ of the schoolchildren found it difficult to concentrate and thought that the homework was boring and uninteresting. $13,7 \%$ of the schoolchildren indicated that homework took them two or three hours, and only 5,9\% of the schoolchildren were doing their homework for up to four hours. The amount of time allotted to homework was increasing with age: e.g., $16,9 \%$ of the $11^{\text {th }}$ form schoolchildren were doing their homework for more than 4 hours. The girls devoted more time to doing homework than the boys. Consequently, a substantial number of the schoolchildren were spending more time on their homework than provided for by hygiene standards. The authors found out that half of the schoolchildren devoted 1 to 2 hours to rest after lessons, while 9,8\% did not have rest at all. They argued that a schoolchild's day lasted as long as an average working adult's one. Adolescents spent six to seven hours per day in lessons and then were doing homework at home. A question arose whether adolescents had enough time not only to prepare for the lessons, but also to take part in non-formal education events or to undertake other favourite activities after school, as well as to health-conducive physical activity.

To grasp the most general trends of harmony between adolescents' leisure, recreation, and physical activity, we thought it was worth finding out their parents' views and viewing schoolchildren's rest from different perspectives. It turned out that almost half of the parent respondents $(47,0 \%)$ thought their children were short of time due to excessive occupation at school and at home, a similar number of them $(34,8 \%)$ stated the children had enough time, and every fifth respondent $(18,2 \%)$ was not sure (Fig. 3). 


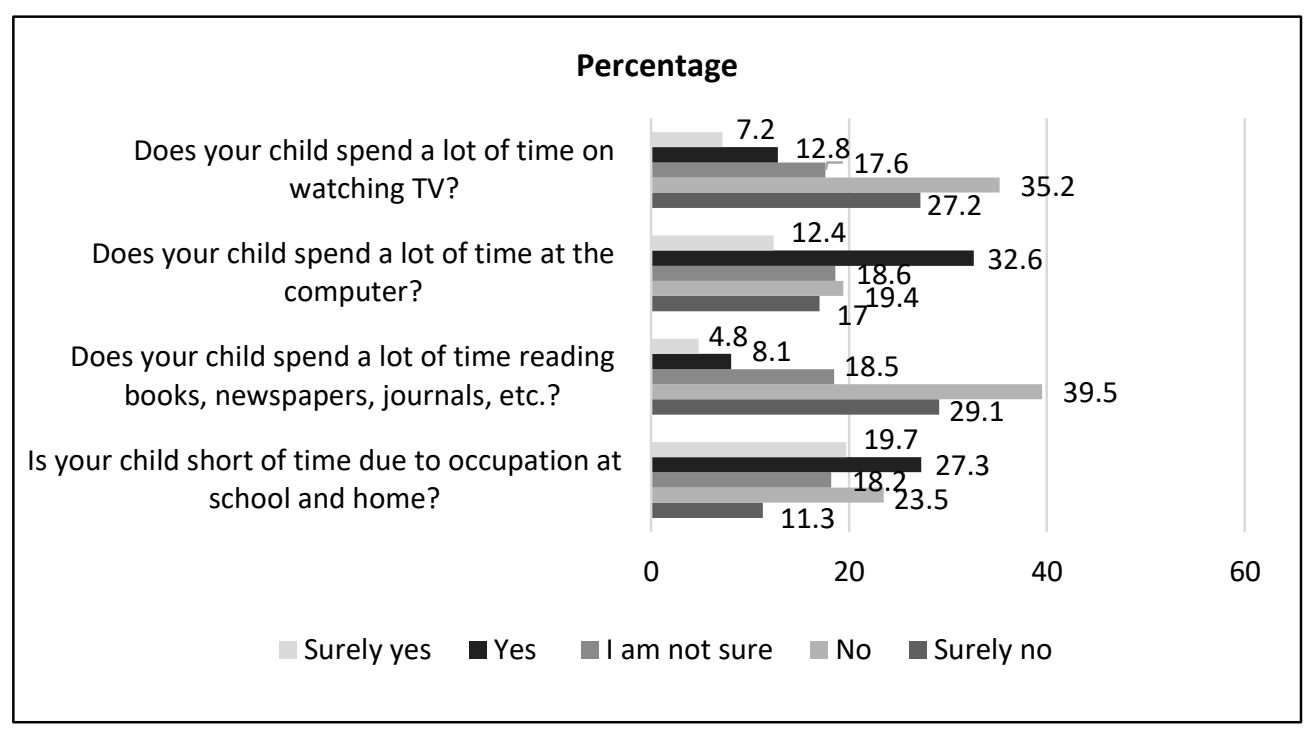

Fig.3 Percentage distribution of parents' views on their children's occupation and sedentary lifestyle

Thus, the trend was identified that about half of the adolescents were rather busy and felt a shortage of time. Therefore, it was important to find out how schoolchildren spent time after classes and what kind of activities predominated: physically active or passive (sitting). For that reason, we sought to establish how much time schoolchildren devoted to reading of books, journals, newspapers, etc. The majority of the parents $(68,6 \%)$ said their children did not spend much time on reading, only every $8^{\text {th }}$ respondent $(12,9 \%)$ indicated the child spent a lot of time sitting and reading, and $18,5 \%$ of the parents were not sure (see Fig. 3).

As seen in Fig. 3, almost half of the parents (45,0\%) stated their children spent a lot of time at the computer, $36,4 \%$ did not think so, and $18,6 \%$ were not sure about the duration of the time at the computer. It should be noted that almost half of the parents indicated their children spent a lot of time in front of the computer screen. As revealed by the research, every fifth $(20 \%)$ respondent thought their child spent a lot of time watching TV, slightly more than half of the parents $(62,4 \%)$ argued adolescents did not devote much time to watching TV programmes, and $17,6 \%$ of the parents were not sure (Fig. 3). As revealed by a detailed analysis of the data, a meaningful relationship existed between the time spent by adolescents at the computer and other after-school activities and their characteristics, i.e. the more time adolescents were staying at the computer and the longer they were doing their homework and spending the leisure time the way they wanted, the less time they were spending outside on weekdays and at weekends or in sports clubs (Fig. 4). 


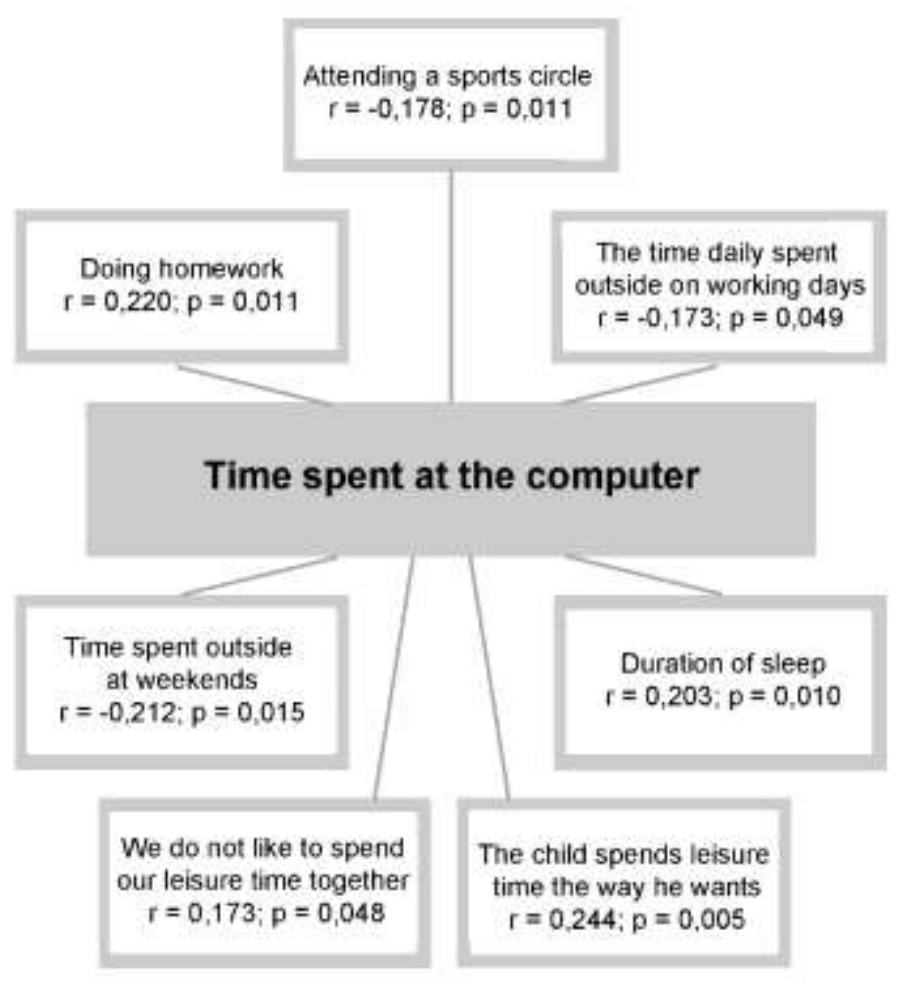

Fig. 4 Correlation between the time spent at the computer and the characteristics of other activities (parents' views)

The data suggest that the summation of the sitting time throughout the day: at school and after school - in front of the computer or TV, reading books, doing homework, etc. - means a huge static load for an adolecent's body. Mental activity is undoubtedly associated with psychophysiological tension, therefore, active leisue is physiologically necesary for the body. Learning and also a physically passive, sitting lifestyle without a possibility to rest and relax by actively moving, playing, exercising, immersing into the state of relaxation, or being active in other ways, can turn into a serious cause of different ailments, illbeing, and the tension in relationships. Active rest which realises an individual's striving to act is physiologically necessary for the body. When the need is not met, the balance between the physical and mental states is violated and may lead to pathological phenomena in the body. The more tense the muscles, the greater neuropsychic tension is experienced by a person, and, on the contrary, muscle relaxation shows neuropsychic calm. By relaxing muscles, one can reduce psychological tension and to affect the development of different disorders. A relaxed and rested person is calm, the mental processes are stabilised, and the emotional and mental state is positively affected. 


\section{The correlation between adolescents' sedentary lifestyle and the characteristics of the after-school activities (from the schoolchildren's viewpoint)}

Adolescents' leisure time differs not merely in the time duration, but also in the way it is spent: some adolescents tend to spend their free time after school in a physically active way (they spend more time outside, play different active games, attend sports clubs, or engage in other activities), while others choose physically passive pastimes, with the prevalence of a sedentary position.

A comprehensive analysis of the research data revealed that a sedentary lifestyle is closely related to adolescents' after-school occupation. A weak direct correlation was established between a sedentary lifestyle and physical inactivity, i.e. the more time adolescents spent reading (books, journals, newspapers, etc.) $(\mathrm{r}=0,16 ; \mathrm{p}=0,000)$ or doing homework $(\mathrm{r}=0,13 ; \mathrm{p}=0,005)$, if they took private lessons $(r=0,18 ; p=0,001)$, spent little time outside $(r=0,48 ; p=0,000)$, spent time at the computer $(\mathrm{r}=0,15 ; \mathrm{p}=0,001)$, and attended non-formal education circles (of art, music, etc.) $(r=0,17 ; p=0,001)$, the more time they stayed sitting and were physically more inactive (Fig. 5).

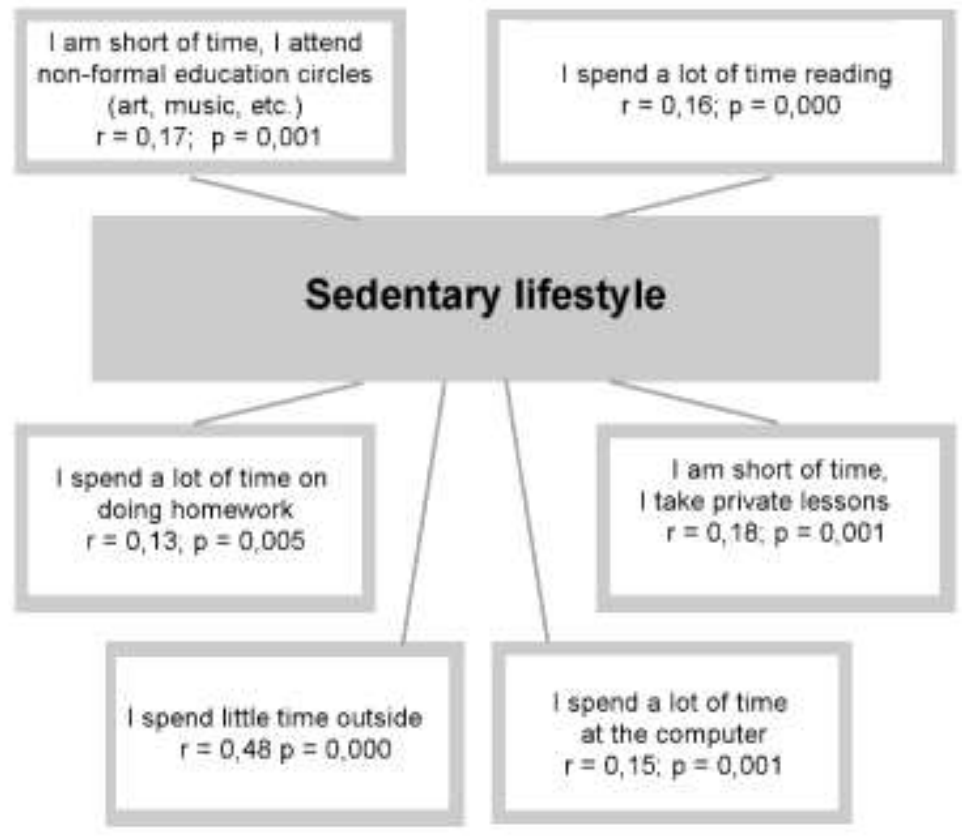

Fig.5 Correlation between adolescents' sedentary lifestyle and physical inactivity (from schoolchildren's viewpoint)

Schoolchildren who have fewer problems related to doing homework, who do not take private lessons and do not attend non-formal education circles related to long periods of physical inactivity, have more time for active pastimes, recreation, and staying in the open air. 


\section{The correlation between adolescents' physical inactivity and non-formal education (from the schoolchildren's viewpoint)}

Research findings demonstrate that the failure to meet the need for physical activity necessary for the normal functioning of the body blocks adolescents' comprehensive development and improvement. As proved by the research (Biddle et al., 2004), the need for physical activity is not limited to the needs of the physical level, but also helps to realise the needs of a higher level: intellectual, spiritual, social, etc.

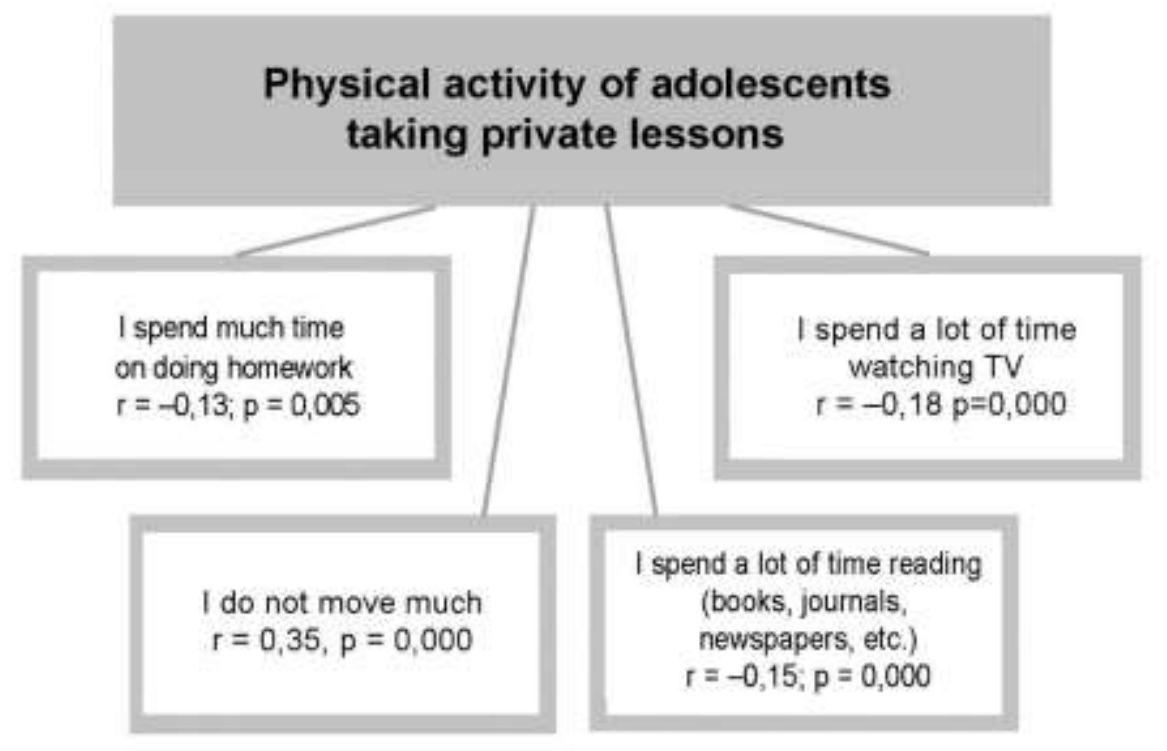

Fig. 6 The correlation between the physical activity and after-school occupation by physically inactive pastime forms of the adolescents taking private lessons (from schoolchildren's viewpoint)

The research findings proved the existence of a statistically meaningful inverse relationship between the adolescents' physical activity and the characteristics of the non-formal education practice. It was established that the adolescents who were taking additional private lessons had less time for rest, an increased workload, and were physically inactive for longer periods of time. Figure 6 presents the inverse relationship between the sedentary lifestyle and physical activity of the adolescents taking additional private lessons. It turned out that the more time was spent by the adolescents on learning - on doing homework $(r=-0,13 ; p=0,005)$ and the longer they were occupied with different physically inactive pastimes, such as watching TV $(\mathrm{r}=-0,18 ; \mathrm{p}=0,000)$ or reading (books, journals, newspapers, etc. $)(r=-0,15 ; \mathrm{p}=0,000)$, the lower their physical activity was. Some schoolchildren, when evaluating their physical activity, admitted they did not move much. The analysis of the data revealed mean direct relationship $(\mathrm{r}=0,35 ; \mathrm{p}=0,000)$ between the schoolchildren's taking additional private 
lessons, physical activity, and their own evaluation of their physical activity. One could assume that the adolescents deliberately chose additional learning outside the formal education seeking to improve their abilities, however, they lacked moral attitudes with respect to an active lifestyle and the competences to adapt to the environment, to maintain the necessary level of physical activity on their own intiative, and to choose health-conducive leisure pastimes.

Lithuanian schoolchildren very frequently indicate that during their leisure hours they spend a lot of time in front of the screens (computer, TV). It would seem that children who take additional private lessons should more often choose health-conducive behaviour and devote more time to active rest: spend less time in fronth of the screens and more time on staying in the open air and on movement, however, the research data fails to confirm the hypothesis, because an inverse statistical activity exists between the issues that characterise schoolchildren's physical activity and the after-school physically inactive pastimes. Therefore, it is necessary to make use of the content of education, the supporting measures, forms, and methods and to create a favourable educational space in the family and at school which would promote health-conducive physical activity and help children develop an active and healthy lifestyle.

\section{Conclusions}

1. The survey revealed that the majority of the 13 and 14 -year-old children respondents indicated being healthy and completely healthy. More boys than girls felt healthy or completely healthy. About half of the adolescents over the last six felt different indispositions: headaches, nervous tension, some adolescents complained of abdominal pain, insomnia, dizziness, and feebleness.

2. Schoolchildren's physical activity depended on their after-school pastimes and after-school educational activities. About half of the surveyed parents believed their children lacked time for active recreation due to overoccupation at school and at home. Children spent too much time sitting in front of computer and TV screens.

3. Adolescents' physicaly inactivity was related to the time spent on ICT (computer, TV), the frequency of their choice, and the duration of doing homework. The more time was spent by adolescents at the computer, on homework, and on leisure activities chosen by themselves, the less time they spent in the open air on weekdays and at weekends and the less they attended sports clubs. The adolescents who took additional private lessons and attended non-formal circles where the sedentary position predominated stood out among peers by a higher level of physical inactivity. 


\section{References}

Andrijauskas, M., \& Batutis, O. (2013). Sédimo laiko ir fizinio aktyvumo ịtaka moksleivių fiziniam pajėgumui. Sportinị darbinguma lemiantys veiksniai (VI). Mokslinių straipsnių rinkinys. Kaunas: LSU, 37-44.

Andriuškienè, J., Varoneckas, G., \& Martinkènas, A. (2007). Sąsajos tarp miego kokybès, depresinès nuotaikos, širdies ir kraujagyslių sistemos būklès ir su sveikata susijusios gyvenimo kokybès. Sveikatos mokslai, 17 (4), 1066-1070.

Baceviciene, M., Luksiene, D. I., Cesnaitiene, V. J., Raubaite, S., Peasey, A., \& Tamosiunas, A. (2012). Dose-response association between physical activity and metabolic syndrome. Central European Journal of Medicne, 8 (2), 273-282.

Barkauskaitè, M., Martišauskienè, E., Gaigalienè, M., Indrašienė, V., Dačiulytė, R., Zybartas, S., \& Guoba, A. (2004). Tiriamojo darbo mokymosi krūviai bendrojo ugdymo mokykloje ataskaita. Vilnius: LR ŠMM, VPU.

Bertheussen, G. F., Romundstad, P. R., Landmark, T., Kaasa, S., Dale, O., \& Helbostad, J. L. (2011). Associations between physical activity and physical and mental health--a HUNT 3 study. Medicine and science in sports and exercise, 43 (7), 1220-1228.

Biddle, S., Gorely, T., Marshall, S. J., Murdey, I., \& Cameron, N. (2004). Physical activity and sedentary behaviors in youth: issues and controversies. Journal of the Royal Society of Health, 124 (1), 29-33.

Bouchard, C., Blair, S. N., \& Haskell, W. L. (2007). Physical activity and health. Human Kinetics.

Boreham, C., \& Riddoch, C. (2001). The physical activity, fitness and health of children. Journal of Sports Sciences, 19 (12), 915-929.

Brunes, A., Augestad, L. B., \& Gudmundsdottir, S. L. (2013). Personality, physical activity, and symptoms of anxiety and depression: the HUNT study. Social psychiatry and psychiatric epidemiology, 48 (5), 745-756.

Dencker, M., Thorsson, O., Karlsson, M. K., Lindén, C., Eiberg, S., Wollmer, P., \& Andersen, L. B. (2006). Daily physical activity related to body fat in children aged 8-11 years. Journal of Pediatrics, 149, 38-42.

Doveikienè, J. (2011). Nesportuojantis jaunimas auga silpnas. Downloaded from http://www.unesco.org/education/pdf/15_62.pdf

Dugdill, L., Crone, D., \& Murphy, R. (2009). Physical Activity and Health Promotion: Evidence-based Approaches to Practice. Wiley-Blackwell Publishing.

Glazer, N. L., Lyass, A., Esliger, D. W., Blease, S. J., Freedson, P. S., Massaro, J. M., \& Vasan, R. S. (2013). Sustained and shorter bouts of physical activity are related to cardiovascular health. Medicine and science in sports and exercise, 45 (1), 109- 115.

Hastings, E. C., Karas, T. L., Winsler, A., Way, E., Wadigan, A., \& Tyler, S. (2009). Young Children's Video/Computer Game Use: Relations with School Performance and Behavior. Issues in Mental Health Nursing, 30 (10), 638-649.

Healy, G. N., Wijndaele, K., Dunstan, D. W., Shaw, J. E., Salmon, J., Zimmet, P. Z., \& Owen, N. (2008). Objectively Measured Sedentary Time, Physical Activity, and Metabolic Risk The Australian Diabetes, Obesity and Lifestyle Study (AusDiab). Diabetes Care, 31, 369371.

Helgadóttir, B., Forsell, Y., \& Ekblom, Ö. (2015). Physical Activity Patterns of People Affected by Depressive and Anxiety Disorders as Measured by Accelerometers: A Cross-Sectional Study. PLoS ONE, 10(1). Downloaded from http: https://www.ncbi.nlm.nih.gov/pmc/ articles/PMC4293141/ 
Horton, R. (2009). Chronic diseases: the case for urgent global action. PubMed. Downloaded from http://www.ncbi.nlm.nih.gov/pubmed/18063030.

Myers, D. G. (2008). Socialine psichologija. Kaunas: UAB Poligrafija ir informatika.

Nedovic, S., \& Morrissey, A. M. (2013). Calm active and focused: Children's responses to an organic outdoor learning environment. Learning Environments Research, 16, 281-295.

Patel, A. V., Bernstein, L., Deka, A., Feigelson, H. S., Campbell, P.T., Gapstur, S. M., \& Thun, M. J. (2010). Leisure Time Spent Sitting in Relation to Total Mortality in a Prospective Cohort of US Adults. American Journal of Epidemiology, 183 (10), 1-10.

Sarradel, J., Generelo, E., Zaragoza, J., Julián, J. A., Abarca-Sos, A., Murillo, B., \& Aibar, A. (2011). Gender differences in heart rate responses to different types of physical activity in physical education classes. Motricidad. European Journal of Human Movement, (26), 65-76.

Skurvydas, A. (2008). Judesiu mokslas: raumenys, valdymas, mokymas, reabiliravimas, sveikatinimas, treniravimas, metodologija. Kaunas: LKKA.

Stokkenes, G., \& Fougner, M. (2011). Physical activity and overweight: Experiences of children and youth in a Norwegian project. Advances in Physiotherapy, 13, 170-176.

Uznienè, R. (2010). Paaugliu medijinès patirties pedagoginé korekcija. Daktaro disertacija Klaipèda: KU leidykla.

World Health Organization. Reducing risks, promoting healthy life (2002). Geneva: WHO.

World Health Organization. Global Strategy on Diet, Physical activity and Health (2004). Geneva: WHO.

World Health Organization. Global status report on noncommunicable diseases (2010). Geneva: WHO.

Zaborskis, A., \& Raskilas, A. (2011). Lietuvos mokinių fizinio aktyvumo pokyčiai 1994-2010 metais. Visuomenés sveikata, 3 (54), 78-86. 